\title{
Humans and Warm Environments
}

\author{
Citation for published version (APA):
}

Pallubinsky, H. (2018). Humans and Warm Environments: Physiology, Health and Behaviour. [Doctoral Thesis, Maastricht University]. Gildeprint Drukkerijen. https://doi.org/10.26481/dis.20180606hb

Document status and date:

Published: 01/01/2018

DOI:

10.26481/dis.20180606hb

Document Version:

Publisher's PDF, also known as Version of record

\section{Please check the document version of this publication:}

- A submitted manuscript is the version of the article upon submission and before peer-review. There can be important differences between the submitted version and the official published version of record.

People interested in the research are advised to contact the author for the final version of the publication, or visit the DOI to the publisher's website.

- The final author version and the galley proof are versions of the publication after peer review.

- The final published version features the final layout of the paper including the volume, issue and page numbers.

Link to publication

\footnotetext{
General rights rights.

- You may freely distribute the URL identifying the publication in the public portal. please follow below link for the End User Agreement:

www.umlib.nl/taverne-license

Take down policy

If you believe that this document breaches copyright please contact us at:

repository@maastrichtuniversity.nl

providing details and we will investigate your claim.
}

Copyright and moral rights for the publications made accessible in the public portal are retained by the authors and/or other copyright owners and it is a condition of accessing publications that users recognise and abide by the legal requirements associated with these

- Users may download and print one copy of any publication from the public portal for the purpose of private study or research.

- You may not further distribute the material or use it for any profit-making activity or commercial gain

If the publication is distributed under the terms of Article $25 \mathrm{fa}$ of the Dutch Copyright Act, indicated by the "Taverne" license above, 


\section{ENGLISH SUMMARY}

\section{Humans and Warm Environments - Physiology, Health and Behaviour}

Nowadays, people in the Western World are rarely exposed to the variation of outdoor conditions, as they spend the greatest part of their day (on average roughly 90\%) indoors. The design of our indoor spaces has developed and changed tremendously over the past decades, to make them as comfortable and optimally tempered as possible. We can heat, cool, humidify, dry and replace the indoor air to our liking, and thus, create a total 'weatherlessness'.

Based on Fanger's research published in the 1970s and the subsequently developed standards for indoor environments according to the American Society for Heating, Refrigerating and Air Conditioning Engineers (ASHRAE), the goal became to strive for a thermally neutral environment in buildings. Thermal neutrality was assumed to be the most comfortable for the majority of building occupants. In order to comply with these indoor environment standards, the ambient temperature of a building is allowed to deviate from the optimal set-point as little as $\pm 0.5^{\circ} \mathrm{C}$, independent of the outdoor temperature and season. Up until today these standards are retained, although maintaining a thermoneutral climate costs a lot of energy for heating and air conditioning of buildings. Importantly, it has also been questioned if such uniform indoor environments are actually healthy. Based on earlier research, it has been suggested that the omnipresence of thermoneutral environments may contribute to the high prevalence and further increasing numbers of obesity and metabolic diseases in developed countries. Furthermore, field studies have shown that people accept a much wider range of ambient temperature than required by the conventional models, which subsequently led to the introduction of the Adaptive Comfort Standard. The latter allows for more variation of the indoor temperature in relation to outdoor temperatures and the different seasons and has been added to the latest ASHRAE Standard 552013.

Measures taken to comply with the classical strict indoor air guidelines described in the above, combined with the endeavour to reduce energy costs, have led to the use of highly isolating construction materials. As a consequence, many modern buildings are nearly air tight, and the hermetic construction style paired with a high internal heat load (due to technical equipment and occupants) puts them at risk for overheating. It becomes particularly difficult to maintain a stable indoor temperature in such airtight buildings when the outside temperature rises and radiation of the sun increases. However, even in cooler winter months, more and more buildings are nowadays at risk for overheating. Due to climate change and global warming, it is expected that people living in Western and Central Europe gradually will be exposed to warm environments more often and more frequently - both indoors and outdoors. 
There has been a lot of scientific interest in studying the impact of extreme temperature conditions on human physiology and health. A vast amount of studies previously investigated the effect of intense, mostly exercise-induced heat acclimation programs on a variety of health-related outcomes and performance parameters. The results of those studies are particularly important to enhance performance and safety of athletes or the military. However, the influence of passive exposure to only moderately increased temperatures, which everybody might encounter in dayto-day situations, is largely unknown. Therefore, the experiments described in this thesis cover effects of acute and longer-term exposure to mild heat on human physiology, behaviour and health.

Metabolic responses of mammals to environmental temperatures can be described in the context of the so-called thermoneutral zone (TNZ). Per definition, within the TNZ, temperature regulation is achieved without changes of energy metabolism or evaporative heat loss. In large mammals such as humans, the determination of the TNZ is compromised due to the need of static conditions in combination with the large heat sink of the body. Therefore, a new dynamic approach to study the TNZ is explored in this thesis (CHAPTER 2). Here, the focus lies on the investigation of the metabolic TNZ, thus the range of ambient temperatures at which the metabolic rate remains stable. The study protocol consisted of an upward (approximately $29^{\circ} \mathrm{C}$ to $38^{\circ} \mathrm{C}$ ) and a downward temperature drift (approximately $29^{\circ} \mathrm{C}$ to $18^{\circ} \mathrm{C}$ ), during which physiological responses of the human body were assessed. The results show that the dynamic protocol is practically feasible and suitable to determine the lower critical temperature (LCT) of the human (dynamic) TNZ, which denotes the critical point at which heat production increases due to decreasing ambient temperatures. Significant inter-individual variation regarding the positioning of the LCT is demonstrated in this thesis, denoted by the wide range of LCTs between the participants $\left(19.2^{\circ} \mathrm{C}-28.9^{\circ} \mathrm{C}\right)$. With respect to the metabolic upper critical temperature (UCT), if at all a slight gradual increase to no metabolic change was observed when temperature increased during warming. Therefore, it was not possible to indicate metabolic UCTs for the great majority of participants. A human metabolic UCT of approximately $32^{\circ} \mathrm{C}$, which has earlier been indicated in the literature, could not be confirmed by the results of this study.

In the context of global warming and the increasing risk for overheating of (modern) indoor spaces, one goal of the present thesis was to evaluate the human capacity for physiological adaptation to relatively mild and passively induced heat acclimation in different study groups. In CHAPTERS 3 and 4, the effect of passive exposure to mild heat (passive mild heat acclimation, PMHA) was studied, simulating realistic everyday life temperature challenges, in a healthy young (CHAPTER 3) and an overweight elderly population (CHAPTER 4). In the healthy population, participants were acclimatised to approximately $33^{\circ} \mathrm{C}$ for $4-6 \mathrm{~h}$ a day at 7 consecutive days. The overweight elderly group endured a slightly longer and more intense protocol with a mean acclimation temperature of $34.5^{\circ} \mathrm{C}$, which lasted for $4-6 \mathrm{~h}$ at 10 consecutive days. During acclimation, thermophysiological parameters such as core and skin temperatures and sweating as 
well as cardiovascular outcomes (e.g. blood pressure and heart rate) were measured. After PMHA, both study groups exhibited significant thermophysiological changes. Most importantly, the results show a significant reduction of core body temperature (Tcore) post PMHA, both in thermal neutrality and during warming. In the healthy population (CHAPTER 3), the decrease of Tcore was approximately $0.14^{\circ} \mathrm{C}$, whereas the overweight elderly group (CHAPTER 4) displayed a slightly more pronounced decrease of approximately $0.19^{\circ} \mathrm{C}$. Total sweat loss, measured as the change of body weight, decreased significantly in the healthy population after PMHA, but no change was observed in the overweight elderly population.

Previous active and passive heat acclimation studies have demonstrated that next to thermophysiological adaptations, prolonged heat exposure goes along with favourable health effects. Many studies report a decrease of resting and exercise heart rate as well as improved endothelial function, decreased arterial stiffness and lowered blood pressure. In both healthy young (CHAPTER 3) and overweight and obese elderly (CHAPTER 4) individuals, a distinct effect of PMHA on blood pressure was evident in thermoneutral conditions as well as during warming. Particularly diastolic blood pressure was lowered after PMHA. Our studies confirm that mild heat treatment might be a promising approach for improving cardiovascular health in a variety of target populations, especially for individuals with limited tolerance for other treatments such as exercise or medication.

In addition to a positive effect on cardiovascular health, it has recently been indicated that repeated exposure to heat might improve glucose metabolism and insulin sensitivity. Regarding the very high prevalence of overweight, obesity, obesity-induced insulin resistance and Type 2 Diabetes Mellitus (T2DM) we are facing today in the Western World, and the failure of current therapy standards to effectively tackle the increasing numbers, new alternative treatment options are needed to facilitate the aspired therapy success and to support long-term sustainability. An earlier study indicated that glucose handling improved in T2DM patients after taking hot baths over the course of 3 weeks, and others suggested a link between repeated heat exposure, increased heat shock protein (HSP) 72 expression and improved insulin sensitivity in human cell experiments and animal studies.

In the study described in CHAPTER 4, the effect of PMHA on glucose metabolism and HSP72 levels in overweight elderly men was assessed. This study is the first to investigate whole-body effects of heat acclimation on glucose metabolism and insulin sensitivity and the potential link with HSP72 levels in human muscle. The results show that PMHA evoked significant changes of glucose metabolism (lowered fasting plasma glucose and fasting plasma insulin), but insulin sensitivity measured by means of hyperinsulinemic-euglycemic clamps and HSP72 expression were not affected by PMHA. Additionally, substrate oxidation in a basal and insulin- stimulated state was evaluated, and a significant decrease of the respiratory quotient and a shift of substrate use towards more fat oxidation and lowered glucose oxidation was measured post-PMHA. Similar 
results have been found after active, exercise-induced heat acclimation. This indicates that both active and passive heat acclimation can cause a substrate switch towards less glucose oxidation but increased fat oxidation in human muscle.

CHAPTERS 2 to 4 of this thesis mainly focus on the evaluation of physiological thermoregulation, i.e. autonomic processes needed to maintain thermal equilibrium of the human body, and adaptive processes of thermophysiology, to prolonged mild heat exposure. Another important aspect of thermoregulation is the conscious behavioural regulation of our thermal environment. In CHAPTER 5, the impact of PMHA on thermoregulatory behaviour and thermal perception in humans was studied. A so-called SWITCH protocol was applied, during which participants were free to go back and forth between a hot $\left(37^{\circ} \mathrm{C}\right)$ and a cold $\left(17^{\circ} \mathrm{C}\right)$ room whenever they desired to change their thermal environment. Skin temperature, thermal sensation and thermal comfort were assessed during SWITCH. For the first time, it is shown that PMHA evokes significant changes of thermoregulatory behaviour: post acclimation, participants switched from the hot to the cold room at higher mean skin temperatures and their stay in the hot room tended to be longer than before the intervention. Hence, participants seemed to tolerate higher skin temperatures before they felt the need to regulate their body temperature, implying greater resilience to heat. This also corresponds to the changes in physiological parameters described in CHAPTER 3 and 4 .

The last study described in this thesis (CHAPTER 6) focused on the evaluation of cooling strategies for optimal thermal comfort in warm environments. Despite the acquisition of physiological adjustments and improved resilience to heat upon heat acclimation (as described in CHAPTERS 3 to 5), warm thermal environments are often perceived as uncomfortable. Therefore, several cooling strategies were tested to identify which body sites are the most suitable and effective to target for the restoration and optimisation of thermal comfort. In a simulated office environment, the application of face cooling (by means of a fan), back cooling (water-perfused seatback), underarm cooling, feet cooling (both by means of a water-perfused cooling plate) and combined face-underarm cooling was tested. Cooling of the face alone as well as combined face-underarm cooling significantly improved both thermal sensation and thermal comfort, representing two relatively easy-to-implement strategies to improve comfort in an office environment. Cooling of the back, the feet, or the underarms alone, did not significantly affect thermal comfort.

The overall goal of this thesis was to evaluate the effect of acute and longer-term mild heat exposure on human physiology, health and behaviour. The results clearly illustrate significant responses of the human thermophysiological system, even during moderate thermal challenges as encountered in everyday life.

Future research is warranted to further elucidate the effects of passive heat exposure in females, since the experiments described in CHAPTERS 2 to 5 only included males. Moreover, further research is needed to test the in-vivo relationships between heat exposure, HSP72 expression and 
insulin sensitivity in humans, both at cellular and at whole-body level. This knowledge may lead to the design of heat therapies and the development of lifestyle interventions as well as more variable, healthy and energy-efficient indoor climate profiles. 